\section{In Epstein's image}

\section{C.T. Pillinger \& I.P. Wright}

Stable Isotopes in High Temperature Geological Processes. Edited by J.W. Valley, H.P. Taylor, Jr, and J.R. O'Neil. Mineralogical Society of America: 1986. Pp.570. Pbk $\$ 18$.

For years there has been a need for an advanced textbook on the geochemistry of stable isotopes $(\mathrm{H}, \mathrm{C}, \mathrm{N}, \mathrm{O}, \mathrm{S}$ and $\mathrm{Si})$. This volume goes half way towards filling the gap by dealing with all aspects of stable isotopes in high-temperature geological processes. Given that its publishers have commissioned a companion publication to cover the subject from the low-temperature standpoint, the problem would now appear to be completely solved.

The book is divided into 14 chapters in which a multiplicity of experts cover theoretical aspects, igneous and metamorphic rocks, ore deposits, the characterization and effects of water-rock interactions, magmatic volatiles and meteorites. Each contribution can be read independently to satisfy an individual need and this is undoubtedly how the book will be used by most of its readers. Although it is priced at a level to be affordable by all, only the very brave, the dedicated or someone with an extended lecture course to give will attempt to read it from cover to cover. This is a pity, because the daunting mathematics of the first few chapters contain the quintessential basis of stable isotope geochemistry. The physical and chemical properties which allow stable isotopes to be partitioned between different phases or substances, and the rules which govern equilibrium and kinetic isotopic fractionation and isotopic exchange in open and closed systems, are the first principles of the subject. But be warned, these are 'first principles' for those who already know what stable isotope geochemistry is.

Elsewhere, the book is extremely readable. For instance, the chapters dealing with oxygen and hydrogen isotope compositions and their relationship with other systems such as $\mathrm{Sr}, \mathrm{Nd}$ and $\mathrm{Pb}$ include a general introduction and overview, examples from the circum-Pacific regions, and case studies from Africa, Eurasia and Oceanic islands. This format will undoubtedly be appreciated by igneous geochemists who are prolific users of stable isotope data.

Two chapters address the subject of isotopic variations within the mantle. Of special interest is the origin and evolution of compositions observed for volatile species. This is a particularly active and controversial topic at present, and even though the relevant chapters were up to date in November 1986 there have already been additional papers to contribute to

couragement. It is a pleasure to join them in their tribute by recommending this book. Perhaps the extent to which the authors have succeeded in their aim is encapsulated in a sentence in the final section of the last chapter. It warns that "[stable] isotopic data alone cannot, under any circumstances, provide meaningful answers to any geologic problem". Such a cautionary note could imply that the gospel has been preached too well.

C.T. Pillinger and I.P. Wright are in the Department of Earth Sciences, The Open University, Walton Hall, Milton Keynes MK $76 A A, U K$.

\section{Complementing the library}

\section{Kenneth Reid}

Immunobiology of the Complement System: An Introduction for Research and Clinical Medicine. Edited by Gordon D. Ross. Academic:1986. Pp.273. \$45.50, £38

THERE must be many people who feel overwhelmed by the current explosion in protein and DNA sequences, and in the uses of DNA probes that are being reported from all areas of biochemistry, including the complement system. They will be relieved to find that this multiauthor volume, describing the many complement components, regulatory proteins and receptors, contains only a couple of short discussions of sequence data (the sections on the thiol ester sites in components $\mathrm{C} 3$ and $\mathrm{C} 4$ and the functionally important residues in the anaphylatoxins), while the review of the recent DNA work is quite brief. This feature is probably a strength rather than a weakness in an introductory account of this sort.

The opening section is a historical review, and contains eight pages of photographs of leading personalities from the early days of complement research. It starts with Nutall's discovery in 1888 that normal sheep blood contains a heat-labile antibactericidal agent, and proceeds up to the early 1970 s. This account will perhaps be of most interest to those already familiar with the system, and it is the following five chapters that make the book valuable as an introduction.

These contributions, which occupy about half of the text, cover the broader molecular aspects at a level which will enable the uninitiated to get a good grasp of the topic. They provide a clear overall view of the essential features of the activation of the classical and alternative pathways, the assembly of the terminal components, and the distribution and function of the increasing number of well-defined receptors. Current views on the activation and control of the alternative pathway, which are often difficult for newcomers to understand, are particularly well described.

The remaining six chapters are of a more variable nature. But they illustrate clearly that any authoritative volume on complement now has to draw upon a wide variety of disciplines, including molecular biology, cell biology, pathology, genetics and various aspects of medicine. This latter part of the book provides a helpful survey of the role of complement in bacterial and viral infections, rheumatic diseases and red cell and platelet injury, as well as overviews of the genetics and biosynthesis of the complement components.

The editor has done well to eliminate repetitive descriptions of the activation of the system which could easily have been a problem in a volume of this type. The book's size and format are appropriate, and most chapters provide pertinent, upto-date references (to 1985 in most cases) for further general reading. Details of the isolation or assay of any particular component were, of course, outside the scope of the book, but it is unfortunate that the authors of the early chapters did not at least provide some references to the literature on practical aspects.

Dr Ross has achieved his aim of producing a palatable introduction to the complement system for those interested in any of its structural, functional, genetic or clinical aspects. The book should therefore make a useful addition to the immunology section of most libraries.

Kenneth Reid is Director of the MRC Immunochemistry Unit in the Department of Biochemistry, University of Oxford, South Parks Road, Oxford $O X 13 Q U, U K$.

\section{New editions}

- Monoclonal Antibodies: Principles and Practice 2nd Edn, by James W. Goding. Publisher is Academic, price is $£ 17.50, \$ 29.50$. For review of the previous edition see Nature 312, 82 (1984)

- Oxford Textbook of Medicine Vols I and II 2nd Edn, edited by D.J. Weatherall et al. Publisher is Oxford University Press, price is $£ 75$ ( $£ 95$ after 30 June), \$135. For review see Nature 303, 204 (1983). 